\title{
Environmental Factors Driving the Toxic Mobility between Soil and Vegetation in Riparian Zone Vegetation
}

\author{
Ayesha Siddiqua ${ }^{1 * * *}$, Yumna Sadef ${ }^{1}$, Sheikh Saeed Ahmad², \\ Mujahid Farid ${ }^{3 *}$, Shafaqat Ali ${ }^{4,5 * *}$ \\ ${ }^{1}$ College of Earth and Environmental Sciences, University of the Punjab, Lahore- 54590, Pakistan \\ ${ }^{2}$ Department of Environmental Sciences, Fatima Jinnah Women University, Rawalpindi, Pakistan \\ ${ }^{3}$ Department of Environmental Sciences, University of Gujrat, Hafiz Hayat Campus, Gujrat, 50700, Pakistan \\ ${ }^{4}$ Department of Environmental Sciences and Engineering, Government College University, Faisalabad, 38000, Pakistan \\ ${ }^{5}$ Department of Biological Sciences and Technology, China Medical University, Taichung 40402, Taiwan
}

Received: 23 October 2020

Accepted: 28 January 2021

\begin{abstract}
The current study for vegetation analysis was carried out along the bank of river Chenab in District Gujrat, Pakistan. Ordination techniques, Canonical Correspondence Analysis (CCA), Detrended Correspondence Analysis (DCA) and TWINSPIN method were used to classify the herbaceous data. A multivariate analysis was employed to assess the connection between the herbaceous flora and environmental factors. Vegetation and soil samples were collected with geographical coordinates. The results revealed that all types of micro and macro nutrients, biotic and abiotic factors have the strongest influence in the existence of plant species and further these factors influenced the both major and minor groups of plant species. Simultaneously Solanum nigrium and Chenopodium berlandieri were found as the most abundant species. Solanum nigrium showed positive response in T-value towards soil moisture and chromium $(\mathrm{Cr})$ while Chenopodium berlandieri showed negative response towards the lead $(\mathrm{Pb})$. The spatial behavior of water quality was explained by an interpolation technique via Inverse Distance Weighted (IDW) to prepare thematic layer maps of all parameters for the Chenab River and this study also provided important information to preserve the herbaceous flora along the bank of Chenab river.
\end{abstract}

Keywords: environmental factors, herbaceous data, Inverse Distance Weighted (IDW), ordination techniques, thematic layer maps

\footnotetext{
*e-mail: mujahid726@yahoo.com

**e-mail: shafaqataligill@yahoo.com

***e-mail: ayesha.siddiqua@uog.edu.pk
} 


\section{Introduction}

Ecological variables play a vital role in the development, management and reclamation of an ecosystem [1]. A large number of ecological researches shows the association between environment and vegetation cover [2-5]. Factors that affect the vegetation growth may include topography, climate, land use planning, natural resource exploitation, hydrologic conditions, and particularly soil characteristics [6-15]. Among different environmental factors, soil plays a vital role in the growth of plant. It is well-known that soil is a function of organisms, climate, time, topography, and parent material [16-17]. The association among soil properties and vegetation characteristics are complex at various stages in terms of vegetation heterogeneity and distribution of plant species. It is important to evaluate the relationships in order to understand various processes of an ecosystem $[18,19]$.

Among various rivers of Pakistan, the river Chenab has to irrigate a large adjacent area [20]. Punjab is the most populous province of Pakistan; it shares 59\% of the gross domestic products and $76 \%$ agriculture production [21]. Gujrat is one of the leading Agririch, industrial and ecologically fertile Districts of the province Punjab. Due to the water resources and fertile land, it is considered as good land for cultivation [22].

The basic objective of this study was to use ordinal techniques for studying existing vegetation status and the effect of various soil characteristics on growing vegetation along Chenab river. Ordinal quantification employs disperse diagrams along 1 or 2 axis or uses points along axis [23]. The technique of ordinal quantification is used in phytosociology for the assessment of vegetation type and cover because of its key importance. Two Way Indicator Species Analysis (TWINSPAN) method was proposed for the classification of plant species and Detrended Correspondence Analysis (DCA) was used for clustering of closely related species as described by [24]; while Canonical Correspondence Analysis (CCA) was formulated for examining the correlation among plant species and environmental parameters [23].

\section{Materials and Methods}

\section{Study Area}

Gujrat is one of the leading agri-rich, industrial and ecologically fertile district of the province Punjab. Area of Gujrat is 3192 square kilometer having three tehsils Gujrat, Kharian and Sarai Alamgir. Gujrat has moderate temperature, as maximum temperature in summer has been reported as $45^{\circ} \mathrm{C}$ and in winter it may fall below $2{ }^{\circ} \mathrm{C}$. The average rain fall in Gujrat is $67 \mathrm{~mm}$ approximately [22]. Gujrat is present between two main rivers of Punjab, river Jhelum and river Chenab. This present study was carried along the bank of Chenab river as given in Fig. 1. Global Positioning System (GPS) device was used for the identification of coordinates along the bank of river, and marked out the points for herbaceous flora and soil data collection.

\section{Data Collection and Chemical Analysis}

Collection of herbaceous flora was done in the month of February and April. Total 40 quadrates 1x1 meter were laid during the present study.

Samples were carefully collected in sampling bags from the depth of 0 to $15 \mathrm{~cm}$ with spade and tagging was done from different areas especially those areas where definite change or mostly anthropogenic activities were involved. 10 samples were taken from different sites. In these soil samples soil texture, saturation, potassium, phosphorus, organic matter, electrical conductivity, $\mathrm{pH}$ and heavy metals like chromium $(\mathrm{Cr})$, lead $(\mathrm{Pb})$, arsenic $(\mathrm{As})$, zinc $(\mathrm{Zn})$, copper $(\mathrm{Cu})$ and nickel (Ni) were checked as described by International Center for Agriculture Research in the Dry Areas (ICARDA) standard methods 2013. Soil samples were air dried and grounded with a wooden pestle, pebbles stones and lager debris were removed from the samples and further it was sieved with the help of $2 \mathrm{~mm}$ sieve for analysis [25].

For chemical analysis, saturated paste percentage method was used to determine the soil texture [25] and Walkley-Black method was used for the calculation of organic matter [26]. $\mathrm{pH}$ was measured by $\mathrm{pH}$ meter with combine electrode and reference electrodes [25]. EC of soil sample was measured by conduit bridge method [25]. The innovative $\mathrm{CuSO}_{4} \cdot 5 \mathrm{H}_{2} \mathrm{O}$ technique formed and explained by Walkley et al. [27] was used for the phosphorous detection [28]. For potassium estimation flame photometer was used.

\section{Data analysis}

Complex datasets of GIS technique represent spatiotemporal variations, prevailing environmental

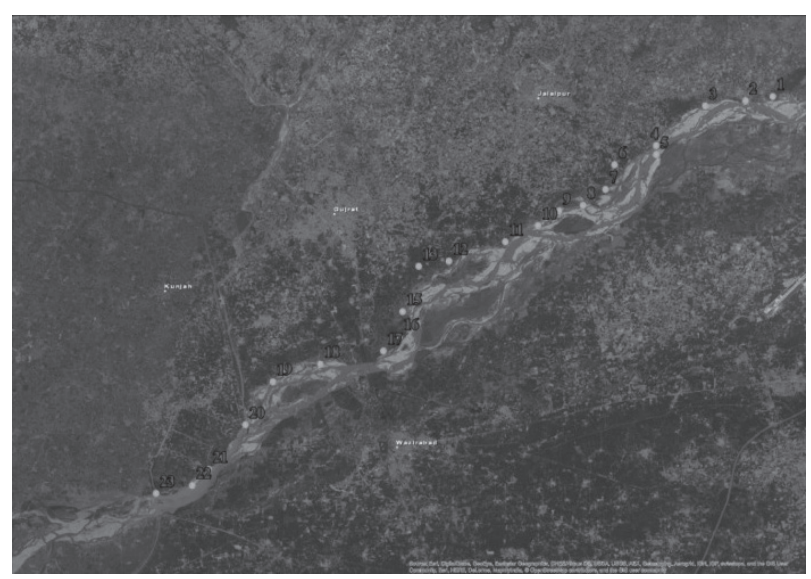

Fig. 1. Study Area and Sampling Sites. 
conditions and climatic fluctuations of any ecosystem in a better way. The coordinate points in the form of point layer file were exported to ArcGIS software along with their analyzed results. Metadata of all the sample were put in the point attribute table after coding. The spatial analyst tool was used to describe the spatial behavior of soil quality. An interpolation technique along with Inverse Distance Weighted (IDW) was used to make thematic layer map of every constraint for the Chenab river [29].

The current study was used for the ordinal assessment of vegetation data for describing close relationship between various plant communities via indirect gradient analyses i.e. Detrended Correspondence Analysis (DCA). Relationship among herbaceous community and environmental data were examined via Canonical Correspondence Analysis.

In the present study, in order to classify standing plant species at the bank of river Chenab and for describing main communities on the basis of abundance and relative frequencies, Two Way Indicator Species Analysis (TWINSPAN) was used with the help of PCORD 5.1 [30].

Canonical Correspondence Analysis (CCA) or direct gradient analysis technique and its sub techniques of partial ordination and Van Dobben circles was applied to explain ecological relationship among soil and existing plant communities. CANOCO 4.5 software program was used to determine Detrended Correspondence Analysis and Canonical Correspondence Analysis [31]. Soil parameters including $\mathrm{pH}$, organic matter, macronutrients, micronutrients and EC were measured for analyzing the effects of various soil characteristics on plant growth.

\section{Results and Discussion}

Results during the vegetation analysis were divided into three sections. Section one; the pattern of vegetation and grouping of different plants populations with the help of TWINSPAN and DECORANA. Section two; data diminution recorded or the overall plant species and their detailed results were described by the second section. Section three; described the relationship between various plant species and communities with different environmental factors collected with the help of Canonical Correspondence Analysis (CCA). Total 50 plants species having 24 families were identified in study area.

\section{Two Way Species Indicator Analysis (TWINSPAN)}

The term TWINSPAN (Two Way Species Indicator Analysis) is based on computer program and used to classify the herbaceous species and samples and used to make the two-way order tables. This table will describe the occurrence of different species in the samples of study area (Table 1). Hierarchal method of classification is the technique of classification that divides the species into categories on the basis of samples. The species of the study area were divided into three different communities. Some of the species were isolated from the communities but they were the part of main group.

In Fig. 2, the presence and absence of species was denoted by two different colures. Black color represents the presence of species and white color represent the absence of species in the samples on the base of cut levels and state community was named based on two most dominant species.

Dendogram was divided into two groups i.e., one major group and one minor group. Major group A contains 2 sub-groups Ala and Alb.

Group Ala consisted of Coronopus didymus, Pistia stratiotes, Calotropis procera, Conyza Canadensis, Eichhornia crassipes, Solanum nigrium, Typha angustifolia and Chenopodium berlandieri. Eichhornia crassipes, Solanum nigrium and Chenopodium berlandieri were dominant in this group, so the group was named as Eichhornia-Solanum- Chenopodium.

Group Alb consisted of Parthenium hysterophorus, Euphorbia helioscopia, Cirsium arvense, Cynodon dactylon, Amaranthus viridis and Anagallis arvensis. This group was dominated by Parthenium hysterophorus and Cynodon dactylon, so the group was named as Parthenium- Cynodon.

Another group was minor group B and was further sub divided into B-1a and B-1b.

Group Bla consisted of Solanum xanthocarpum, Melilotus indica, Tamarisk, Ipomea carnea lsa. This group was dominated by Melilotus indica and Tamarisk, so the group was named as Melilotus- Tamarisk

Group B1b consisted of Solanum surattense, Calystegia hederacea and Osmunda rejeles. This group was dominated by Calystegia hederacea and Osmunda rejeles so the group was named as Calystegia- Osmunda

Similar study was conducted by Khan et al. [24], to examine weeds data along Khanpur dam. Khan et al. [32] studied the ecological relationship of plants and environmental variables using TWINSPAN software of natural resources in Soon Valley, Khusab. In 2018, Zia et al. [33] used the same technique to study vegetation of district Narowal. The road side vegetation's of Wah Cantonment was analyzed by $\mathrm{Lu}$ and Wong, [30] by using TWINSPAN.

\section{Dominance Curve}

Fig. 3 was formulated to identify the dominance of the species in study area by formulating the rank. In this study the graph was developed using the rank of abundance in opposition to log sum values, species were plotted on the graph according to their dominance over the study area. This is scatter plot graph and it showed the most abundant species was Anagallis arvensis, Cynodon dactylon was second and the third was Amaranthus viridis. The other dominant species, of 
Table 1. Identification of Species and Their Families along Chenab River.

\begin{tabular}{|c|c|c|c|c|c|}
\hline No. & Scientific Name & Family & No. & Scientific Name & Family \\
\hline 01 & Coronopus didymus & Brassicaceae & 02 & Pistia stratiotes & Araceae \\
\hline 03 & Calotropis procera & Apocynaceae & 04 & Eichhornia crassipes & Pontederiaceae \\
\hline 05 & Cynodon dactylon & Poaceae & 06 & Solanum xanthocarpum & Solanaceae \\
\hline 07 & Parthenium hysterophorus & Asteraceae & 08 & Solanum surattense & Solanaceae \\
\hline 09 & Conyza canadensis & Asteraceae & 10 & Melilotus indica & Fabaceae \\
\hline 11 & Osmunda rejeles & Osmunda & 12 & Amaranthus viridis & Amaranthaceae \\
\hline 13 & Solanum nigrium & Solanaceae & 14 & Tamarisk & Tamaricaceae \\
\hline 15 & Euphorbia helioscopia & Euphorbiaceae & 16 & Calystegia hederacea & Convolvulaceae \\
\hline 17 & Chenopodium berlandieri & Amaranthaceae & 18 & Anagallis arvensis & Primulaceae \\
\hline 19 & Achyranthes aspera & Amaranthaceae & 20 & Cannabis sativa & Cannabaceae \\
\hline 21 & Silybum marianum & Asteraceae & 22 & Arctium tomentosum & Asteraceae \\
\hline 23 & Malva parviflora & Malvaceae & 24 & Xanthium spinosum & Asteraceae \\
\hline 25 & Datura stramonium & Solanaceae & 26 & Asphodelus tenuifolius & Xanthorrhoeaceae \\
\hline 27 & Carthamus oxyacantha & Asteraceae & 28 & Cirsium arvense & Asteraceae \\
\hline 29 & Xanthium strumarium & Asteraceae & 30 & Typha angustifolia & Typhaceae \\
\hline 31 & Verbascum thapsus & Scrophulariaceae & 32 & Avena fatua & Poaceae \\
\hline 33 & Phalaris minor & Poaceae & 34 & Sisymbrium irio & Brassicaceae \\
\hline 35 & Ipomea carnea lsa & Convolvulaceae & 36 & Medicago littoralis & Fabaceae \\
\hline 37 & Vicia sativa & Fabaceae & 38 & Tribulus terrestris & Zygophyllaceae \\
\hline 39 & Pоа аппиа & Poaceae & 40 & Lathyrus aphaca & Fabaceae \\
\hline 41 & Setaria viridis & Poaceae & 42 & Justicia adhatoda & Acanthaceae \\
\hline 43 & Chrozophora tinctoria & Uphorbiaceae & 44 & Eclipta & Asteraceae \\
\hline 45 & Cichorium intybus & Asteraceae & 46 & Artemisia scoparia & Asteraceae \\
\hline 47 & Saccharum spontaneum & Poaceae & 48 & Polygonum monspeliensis & Polygonaceae \\
\hline 49 & Eleusine indica & Poaceae & 50 & Dichanthium annulatum & Poaceae \\
\hline
\end{tabular}

the study area was observed from the dominance curve shown in the Fig. 3.

\section{Canonical Correspondence Analysis (CCA)}

Multivariate analysis was the most adaptable technique. The ordinate space for CCA analysis and dispersion of species in analysis were same as the DCA. This was the direct analysis technique and environmental gradients and the response of species were noticed by using different techniques and application of CCA analysis. There were different variables used for the species and variables of soil that were co- related with soil moisture, $\mathrm{pH}, \mathrm{EC}, \mathrm{P}, \mathrm{K}, \mathrm{As}, \mathrm{Ni}, \mathrm{Cr}, \mathrm{Pb}$ and $\mathrm{Cu}$. The triangle signified the single species whereas the arrow head identified the environmental species. Maximum change of environmental factors was signified by the points on the diagram. Length of the arrow also represented the maximum change and their magnitude was proportional to the change in the environmental variables. Larger the length more the impact and influence on the single species so $\mathrm{EC}, \mathrm{OM}, \mathrm{Pb}$ and $\mathrm{Ni}$ had the longest length of arrow head because these factors showed strongest influence on the growth of species. Due to this reason, only Parthenium hysterophorus was able to show the correspondences towards OM, Coronopus didymus towards $\mathrm{Cr}, \mathrm{K}$ and $\mathrm{P}$ have same lengths of arrows heads. In the case of saturation, there was no species around the arrow however $\mathrm{Zn}$ have the smallest length of arrow but Cynodon dactylon showed the correspondence towards $\mathrm{Zn}$. The species that were away from the environmental arrow heads were free from the influence of the environmental gradients as shown in Fig 4. 

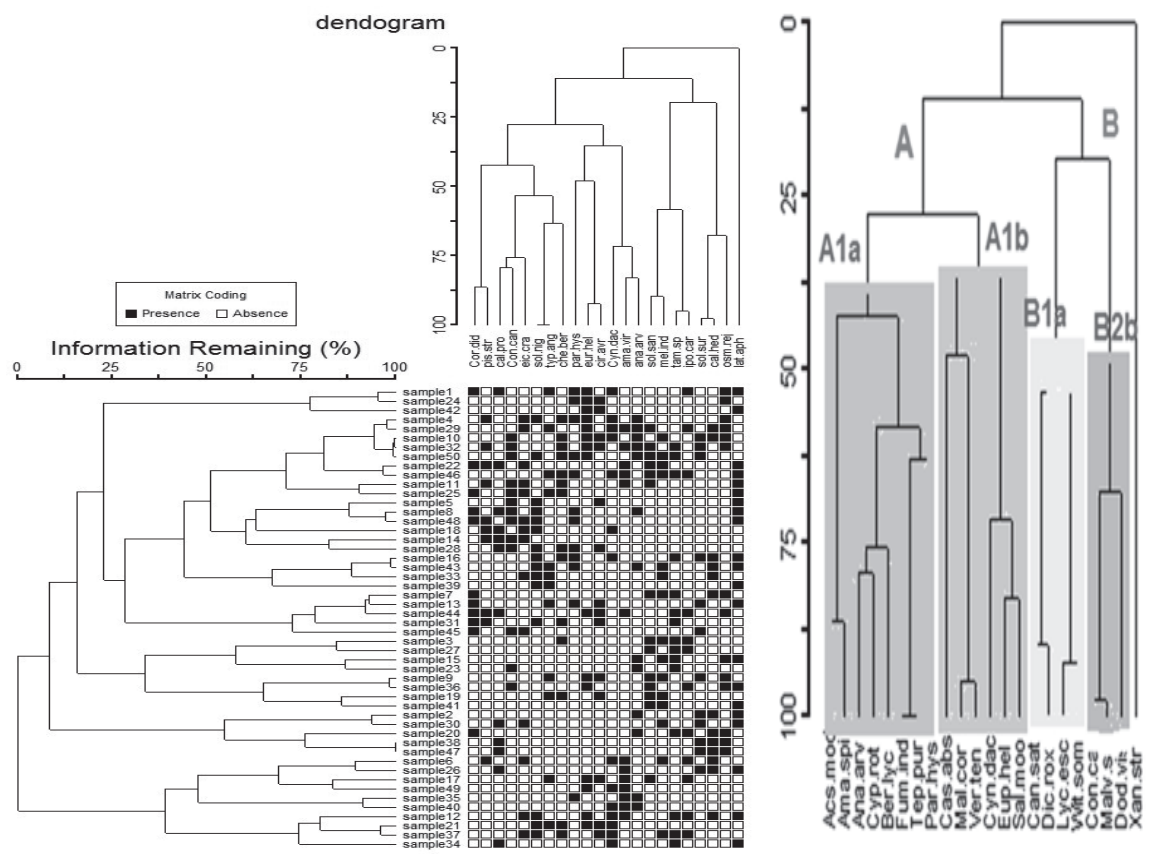

Fig. 2. Two Way Species Indicator Analysis delineated groups and communities.



Fig. 3. Dominance Curve: The scatter plot graph showed the most abundant species.

\section{T-value Biplot}

T-value biplot is the statistical technique used as tool to produce the special kind of bioplots in this Van Dobben circles were formed that explained the response of different species towards environmental variables (soil moisture, $\mathrm{pH}, \mathrm{EC}, \mathrm{P}, \mathrm{K}, \mathrm{As}, \mathrm{Ni}, \mathrm{Cr}, \mathrm{Pb}$ and $\mathrm{Cu}$ ). Arrow heads represent the species while triangle symbol represent the environmental variables. Species with the arrows in the same circle represents the T-value statistics ${ }^{+} 2$ or -2 . The environmental points are shown outside the interval thus showing $\mathrm{T}$-value was greater than ${ }^{+} 2$.

The T-value Biplot represented the association between the soil organic matter (OM) and different vegetation species present in the study area. This parameter had the strong impact on the growth but 


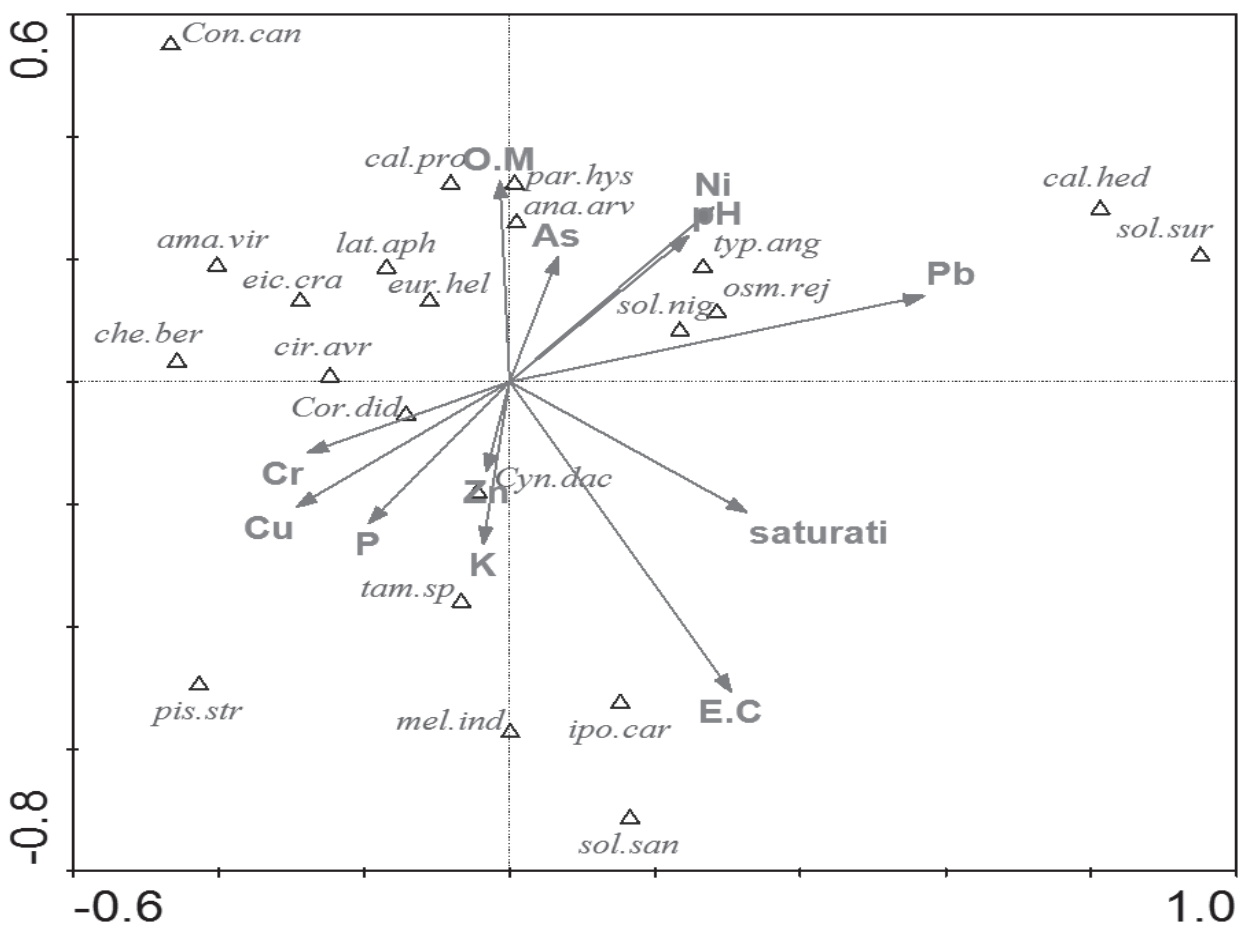

Fig. 4. Canonical Correspondence Analyses (CCA): The triangle signified the single species whereas the arrow head identified the environmental species. Length of the arrow represented the maximum change and their magnitude was proportional to the change in the environmental variables.

species growth was also influenced by the presence and absence of the OM. As Calotropis procera, Anagallis arvensis, Parthenium hysterophorus, Calystegia hederacea and Euphorbia helioscopia showed positive response while Coronopus didymus, Pistia stratiotes and Cynodon dactylon showed negative response related to the T-value Biplots. Mostly species shows positive response that $\mathrm{OM}$ has influence on plant species.

Electrical conductivity (EC) was also prominent factor in the growth of vegetation. Dobben circles expressed the positive and negative response of species towards EC. Red circle showed positive response while blue circle showed negative response. Solanum xanthocarpum showed the strongest positive response. Other species showed positive response for EC were Melilotus indica, Cynodon dactylon, Ipomea carnea lsa, Pistia stratiotes and Tamarisk. While Conyza canadensis showed strongest negative response for EC. Furthermore, the species passing through blue circle also showed negative response towards EC.

T-Value for soil moisture/ saturation represented the relationship between the soil moisture and vegetation of study area. No species was strongly affected by the saturation of soil but few species showed positive response and those species were Solanum xanthocarpum, Solanum surattense, Solanum nigrium, Tamarisk and Pistia stratiotes. However, few other species were also passed through the red circle. Conyza canadensis showed strongest negative response and species passing through blue circle showed negative response. Other species have less influence of soil moisture on growth.

T-value for the Potassium (K) showed that Pistia stratiotes was positively influenced by the $\mathrm{K}$ and Calystegia hederacea and Solanum surattense showed negative response because they were not influenced by the presence or absence of $\mathrm{K}$ in the soil. While other species passed through the circles are not much influenced by the $\mathrm{K}$ content.

Phosphorous (P) is also an important constituent for the plant growth. $\mathrm{T}$-value of $\mathrm{P}$ also showed the relationship between the available $\mathrm{P}$ and growth of vegetation. Species Solanum xanthocarpum, Melilotus indica, Ipomea carnea lsa and Tamarisk showed positive responses' while Calystegia hederacea showed the strongest negative response.

T-value for the $\mathrm{Pb}$ presented that some species showed strongest positive and strongest negative response. Solanum surattense and Calystegia hederacea showed the strongest positive response and Chenopodium berlandieri and Cirsium arvense showed negative response. Other species were slightly influenced by the presence of $\mathrm{Pb}$.

The T-value projects the linkage between the As and different plant species found in the study locale. The soil parameters have direct impact on the flora growth however these species have positive or negative response was linked with presence/ absence and concentration of environmental variables. Here, in the present study, 
a)



c)

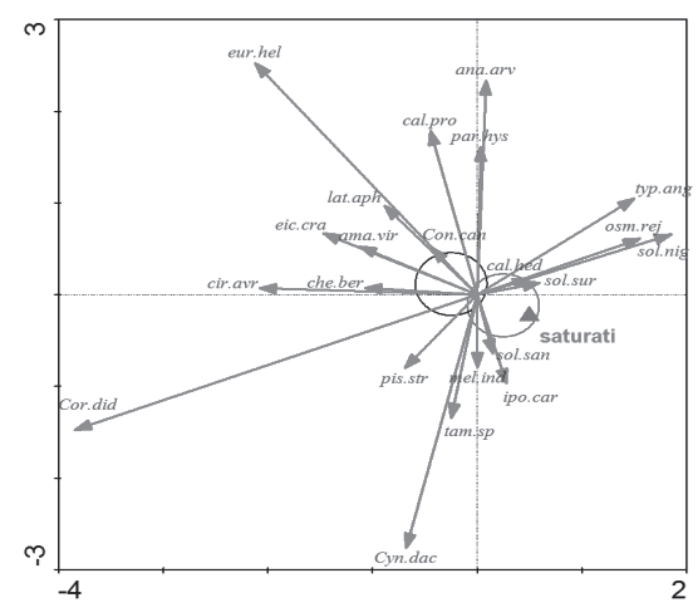

e)

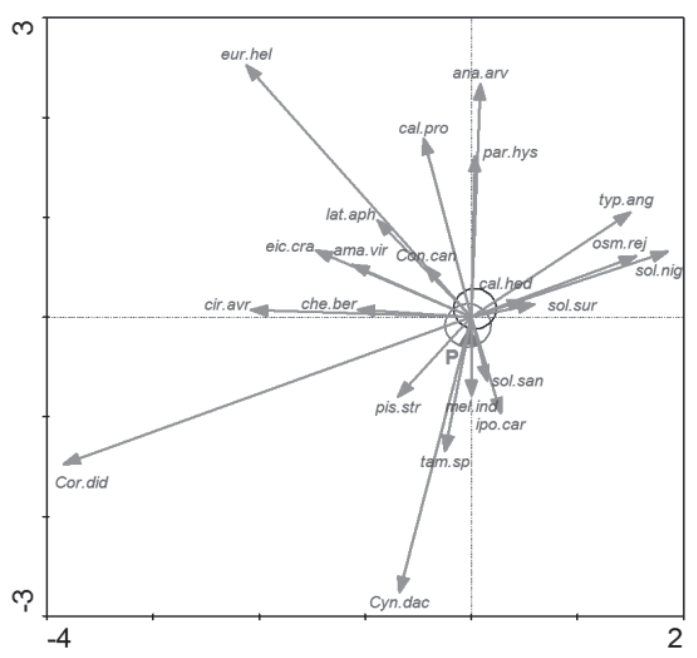

b)

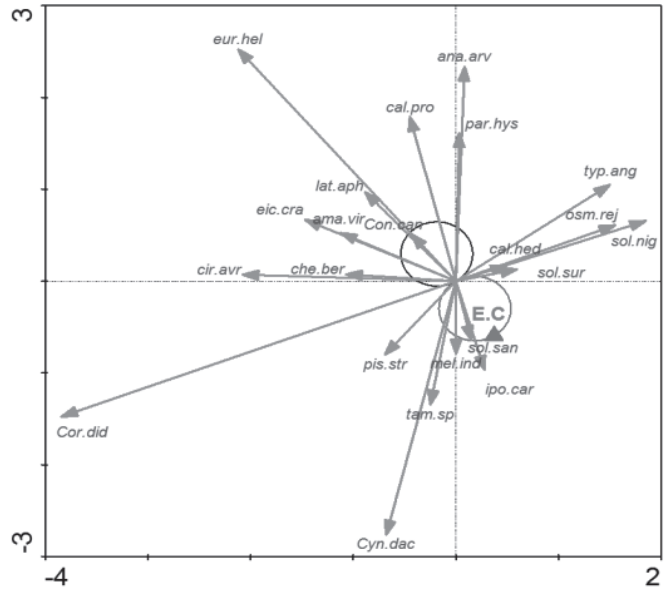

d)



f)

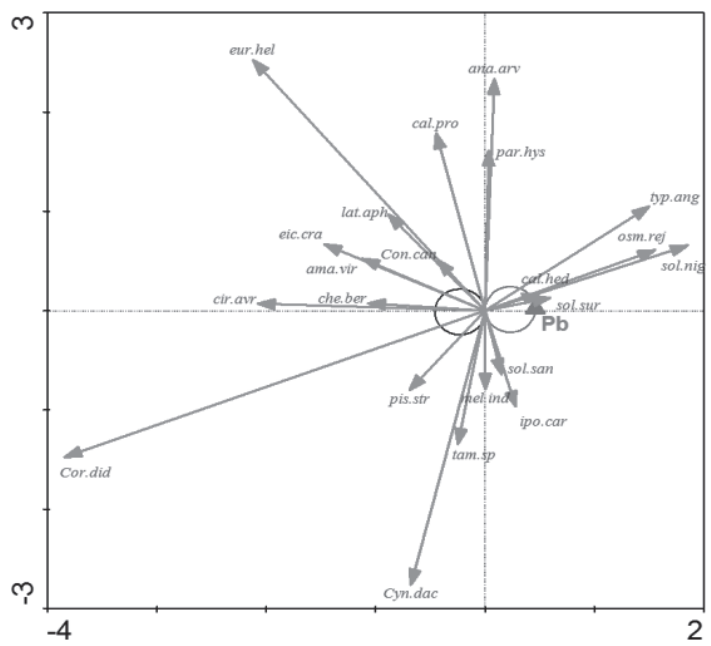

Fig. 5 a) T-value Biplot for Soil, b) T-value Biplot for EC Organic Matter, c) T-Value Biplot for Soil Moisture, d) T-Value Biplot for Potassium, e) T-Value Biplot for phosphorous, f) T-Value Biplot for lead (Pb), g) T-Value Biplot for Arsenic (As), h) T-Value Biplot for Chromium (Cr), i) T-Value Biplot for Copper (Cu), j) T-Value Biplot for Nickel (Ni). Arrow heads represent the species while triangle symbol represent the environmental variables. Species with the arrows in the same circle represents the T-value statistics ${ }^{+} 2$ or ${ }^{-2}$. The environmental points are shown outside the interval thus showing T-value was greater than ${ }^{+} 2$. 
g)

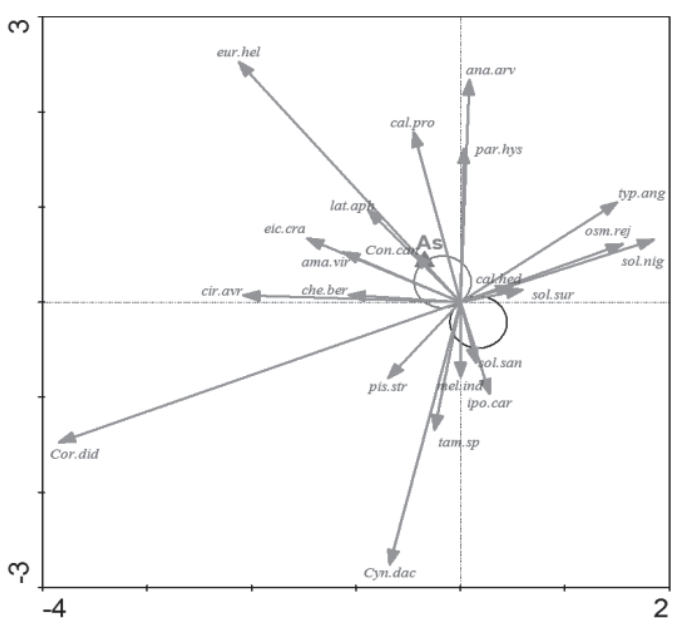

i)

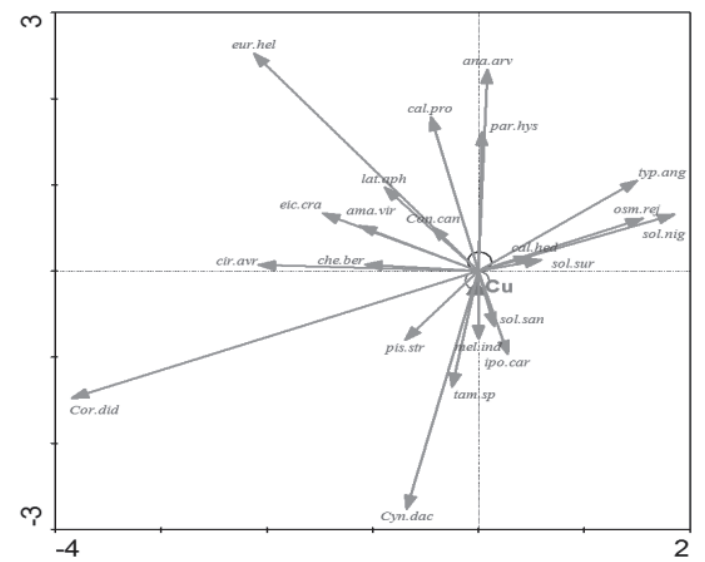

h)

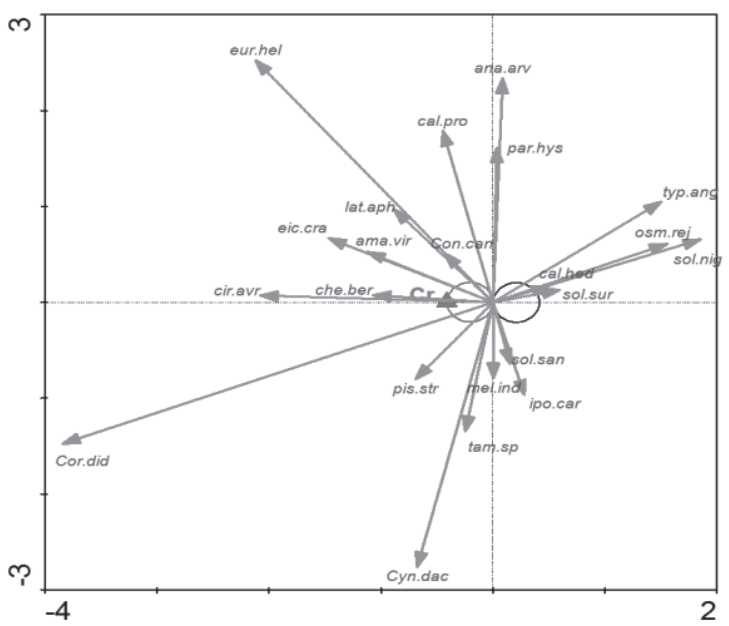

j)

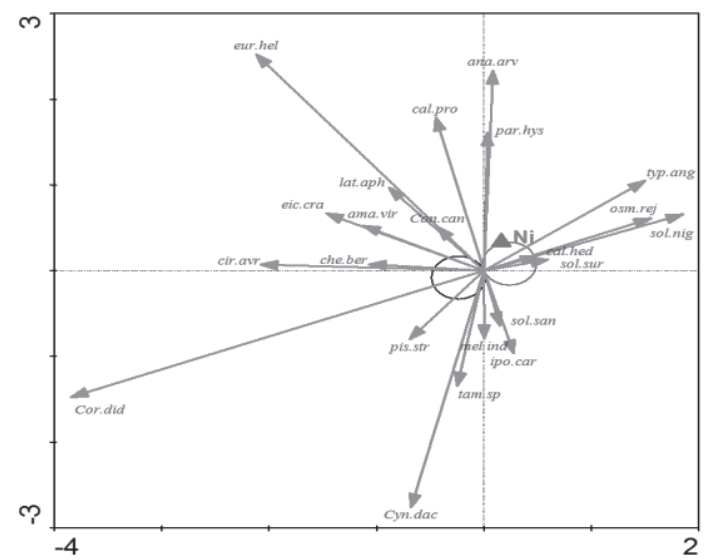

Fig. 5(a-j). Continued.

the species Conyza canadensis and Lathyrus aphaca showed positive response along with other species passed through red circle. Ipomea carnea lsa, Melilotus indica and Solanum xanthocarpum showed negative response towards presence or absence of As.

The T-value regarding available $\mathrm{Cr}$ also depicted that Chenopodium berlandieri and Cirsium arvense showed positive response while Solanum surattense and Calystegia hederacea showed the strongest negative response. Most of the lines of plant species were passed through red circle which shows that these species showed positive response towards environmental variables.

The vegetation species were represented by arrow head and Dobben circles with help of colures that determined the positive and negative responses. T-value Biplot for flora represents that Solanum xanthocarpum, Melilotus indica and Ipomea carnea lsa were closed to the environmental variable and showed stronger positive response related to other species passed through red circle. While species like Parthenium hysterophorus passing from blue circle showed negative response against $\mathrm{Cu}$.
The T-value Biplot diagram regarding available $\mathrm{Ni}$ presented that no species showed strongest response while Calystegia hederacea and Solanum surattense showed positive response. However, most of species were passed through negative circle and Pistia stratiotes showed strongest negative response against $\mathrm{Ni}$.

\section{Pie Symbol Plot}

In the present study every environmental variable was divided into different classes according to the number of samples using different symbols. The space of symbols tells the relative abundance in each plot. The current study gave the results of absence or presence of plant species in these classes.

Species were divided into four classes. Pie chart for $\mathrm{pH}$ was ranged from 7.0-7.8 with average value of 7.49. Class 1 contained 20 members while others three classes contained 10 members each however the dominant class contained most of the vegetation samples.

In the case of OM, the environmental variables were divided into four classes with range from 0.2 to 0.67 and has the average value of 0.291 . The species 
a)

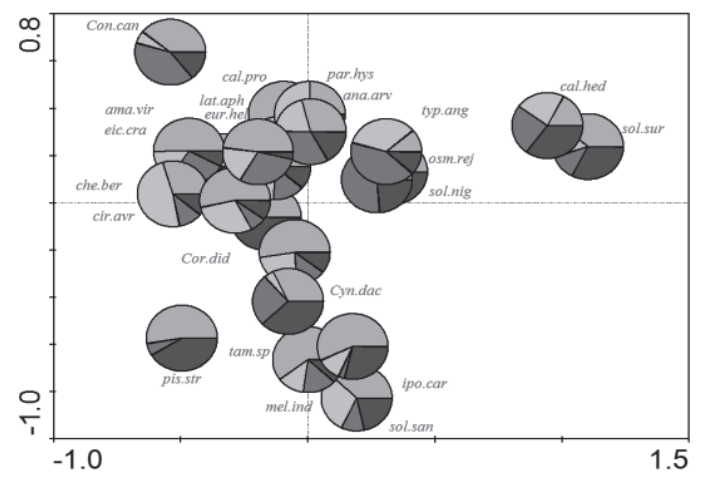

\begin{tabular}{l} 
SPECIES PIES CLASSES \\
$\square \mathrm{pH}-1 \quad \square \mathrm{pH}-2 \quad \square \mathrm{pH}-3 \quad \square \mathrm{pH}-4$ \\
\hline
\end{tabular}

c)

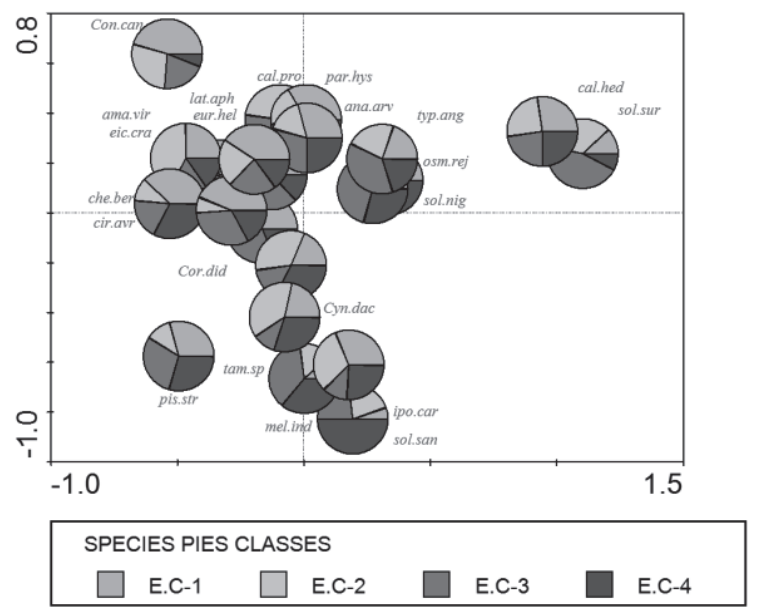

b)

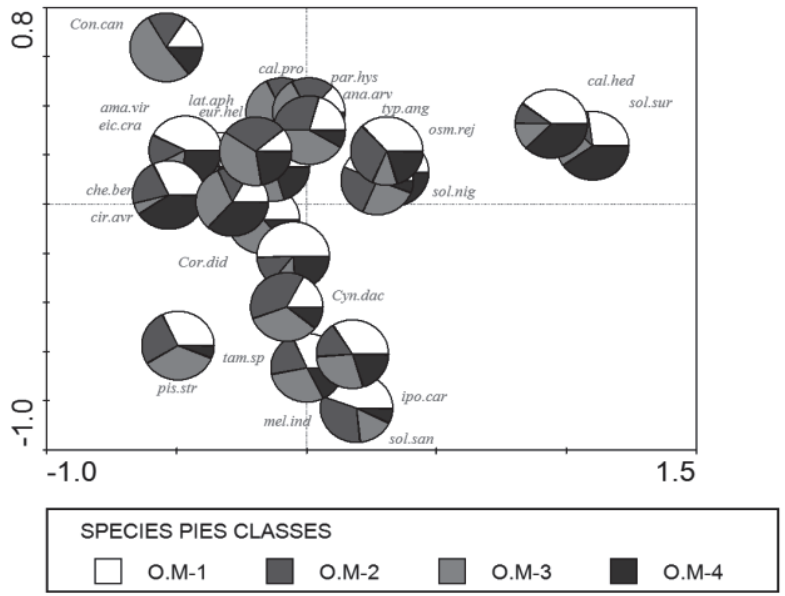

d)
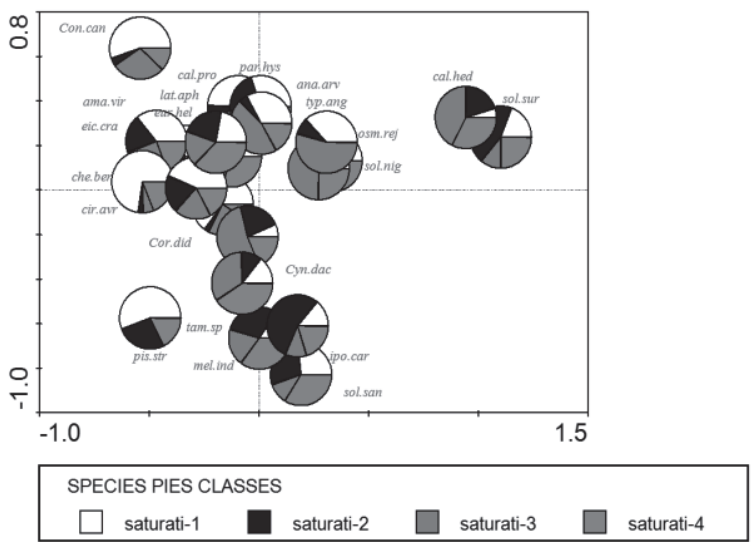

f)

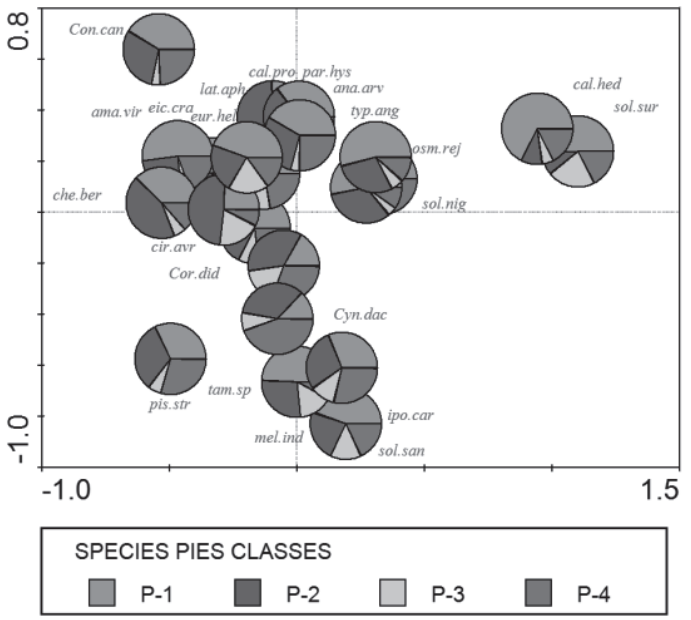

Fig. 6 a) Soil pH pie Symbol Plot, b) Soil Organic Matter pie Symbol Plot, c) Soil Electrical Conductivity, d) Soil moisture Pie Symbol Plant Pie Symbol Plot, e) Available Potassium Pie Symbol Plot, f) Available Phosphorus Pie Symbol Plot,. g) Lead Pie Symbol Plot, h) Arsenic Pie Symbol Plot, i) Chromium Pie Symbol Plot, j) Copper Pie Symbol Plot, k) Nickel Pie Symbol Plot, 1) Zinc Pie Symbol Plot. Environmental variables were divided into different classes according to the number of samples using different symbols. The space of symbols tells the relative abundance in each plot. This figure gave the results of absence or presence of plant species in these classes. 
with class 1 having maximum richness. The EC was recorded in the range of 0.95 to 1.94 with average value of 1.404 .

Soil moisture was the component for survival of species in the study area. The soil moisture content was observed in the range from 32 to 60 with average value of the 42.4. The moisture content was divided into four classes where class 1 contained 15 , class 2 contained 10 , class 3 contained 13 and class 4 contained 12 members.

The range of $\mathrm{K}$ was measured in the range of 61 to 163 with average value of 88.5 . The species were divided into 4 classes; class $1 \& 2$ contained 13 while class 3 \& 4 contained 12 members each however the class 1 was dominant class.

Phosphorus (P) was also divided into four classes and its range started from 3 to 8 and it showed the average value of 4.3. In the results, class 1 have 20 members, class 2 have 14, class 3 have 6 and class 4 have 10 members. However, the class $1 \& 2$ showed richness in diversities of species.

The range of $\mathrm{Pb}$ was found between -0.2 to 3.24 with average value of 2.057. Species were divided into 4 classes contained different members such as class 1 and 3 contained 13 members while class 2 and 4 contained 12 members each however class 4 contained best species richness.

Arsenic (As) is also an important component for survival of vegetation species in the study area. The range of the As started form the -5 to 10 with the average value of 6 . Species were divided in to four classes where class 1 and 3 contained 13 members while class 2 and 4 contained 12 members. Class 4 supported growth of maximum species.

The range of $\mathrm{Cr}$ was found between 0.015 to 0.1 with the average value of 0.0559 . Species were divided into 4 classes with class 1 having 18 , class 2 having 8 , class 3 having 16 and class 4 having 8 members. Class 1 showed maximum richness in diversities of species.

The range of $\mathrm{Cu}$ started from 1.98 to 3.25 and have average value of 2 . Species were divided into 4 classes with class 1 containing 14 members, class 2 containing 11 members, class 3 containing 13 members and class 4 containing 12 members. Class 3 showed higher species richness.

Environmental variable $\mathrm{Ni}$ was also divided into four classes. Its range was found between 1.68 to 1.12 and has the average value of 1.2. The species were distributed as 13, 14, 11 and 12 members in four classes respectively. Majority of the plants were showed in every class but class 2 showed prominent richness.

$\mathrm{Zn}$ was found in the range between -1.6 to 0.01 with the average value of -0.0423 . The species were distributed as 14, 11, 13 and 12 members in four classes respectively. The majority of the plants were showed in each class however the class 1 was with prominent richness as shown in Fig. 61).

Chenab river was very rich in vegetation along with different flora types while doing survey about 60 different types of herbaceous flora are collected from study site village Dhool to Head khanki. Vegetation data was monitored by the ordination techniques by using method of TWINSPIN, CCA and DCA. Some the species were isolated from the communities but they were the part of main group. Zereen et al. [34] studied T-value bi-plots and applied the effect of altitude on vegetation growth. Species that were positively correlated with altitude passed through red circle while those whose growth was suppressed by altitude were passed through blue circle.

In the study area of river Chenab, plants species were divided into major groups $\mathrm{A}$ and minor group B. Group A was further divided into subgroups Ala contained dominant group Eichhornia-SolanumChenopodium and Alb contained Parthenium-Cynodon dominant group. Minor group B was also divided into Bla had dominant group Melilotus- Tamarisk and B1b had Calystegia- Osmunda. Eichhornia crassipes, Solanum nigrium and Chenopodium berlandieri were most abundant species. All types of nutrients' including micro and macro nutrients, biotic and abiotic factors had the strongest influence in the existence of plant species and they were influencing both major and minor groups. Partial ordination had estimated the probability of the effects of environmental parameters in community structures at different range level for same variable [35]. In a similar study Zia et al. [33] investigated the relationship between plant distribution and ecological factors of district Narowal, Pakistan and described the importance of vegetation cover for preventing soil erosion and providing food and habitat for wild life. Moreover, a study conducted by Khan et al. [32] reported the correlation of wet land complex of Soon valley of Pakistan.

\section{Conclusion}

The results of the present study concluded that the growth of plants was under the influence of various soil properties including soil nutrients, soil inorganic ions, and soil physical property however their effects were according to the sample locality. Keeping in view the current scenario and result the current vegetation cover along Chenab river in Gujrat Pakistan is facing many troubles due to straight flooding, agricultural practices, over grazing, soil erosion, deforestation and expansion like construction, industrial development responsible for the change in environmental variables.

\section{Acknowledgement}

The present research work is the part of $\mathrm{PhD}$ research work of Ms. Ayesha Siddiqua. The authors are thankful to the Punjab University, Lahore, Pakistan for support during the research work and analysis. 


\section{Conflict of Interest}

The authors declare no conflict of interest

\section{References}

1. MARTY C., HOULE D., GAGNON C., COURCHESNE F. The relationships of soil total nitrogen concentrations, pools and $\mathrm{C}: \mathrm{N}$ ratios with climate, vegetation types and nitrate deposition in temperate and boreal forests of eastern Canada. Catena, 152, 163, 2017.

2. JIANG Y., ZANG R., LETCHER S.G., DING Y., HUANG Y., LU X., ZHANG Z. Associations between plant composition/diversity and the abiotic environment across six vegetation types in a biodiversity hotspot of Hainan Island, China. Plant and soil, 403 (1-2), 21, 2016.

3. BREEN D.B., BEAUCHAMP V.B., KOONTZ S.M., ROBERTS R.P. The influence of agricultural abandonment and the abiotic environment on the vegetation communities of a suburban deciduous forest. Castanea, 80 (2), 103, 2015.

4. NELSON P.R., MCCUNE B., SWANSON D.K. Lichen traits and species as indicators of vegetation and environment. The Bryologist., 118 (3), 252, 2015.

5. ZHOU J., FU B., GAO G., LÜ Y., LIU Y., LÜ N., WANG $\mathrm{S}$. Effects of precipitation and restoration vegetation on soil erosion in a semi-arid environment in the Loess Plateau, China. Catena, 137, 1, 2016.

6. ALEXANDRE P.M., STEWART S.I., MOCKRIN M.H., KEULER N.S., SYPHARD A.D., BAR-MASSADA A., RADELOFF V.C. The relative impacts of vegetation, topography and spatial arrangement on building loss to wildfires in case studies of California and Colorado. Landscape ecology, 31, (2), 415, 2016.

7. CHAU N.L., CHU L.M. Fern cover and the importance of plant traits in reducing erosion on steep soil slopes. Catena, 151, 98, 2017.

8. YU M., WANG G., \& PAL J.S. Effects of vegetation feedback on future climate change over West Africa. Climate dynamics, 46 (11-12), 3669, 2016.

9. WANG Z., DENG X., SONG W., LI Z., CHEN J. What is the main cause of grassland degradation? A case study of grassland ecosystem service in the middle-south Inner Mongolia. Catena, 150, 100, 2017.

10. CHU D., LU L., ZHANG T. Sensitivity of normalized difference vegetation index (NDVI) to seasonal and interannual climate conditions in the Lhasa area, Tibetan plateau, China. Arctic, Antarctic, and Alpine Research, 39 (4), 635, 2007.

11. YAGOUB Y.E., MUSA O.S., SIDDIG A.A., BO Z., LI Z., WANG F. Assessing the Impacts of Land Use Changes on Vegetation Cover in Eastern Sudan. International Journal of Research in Agricultural Sciences, 4 (2), 70, 2017.

12. ZHANG Y., ZHANG C., WANG Z., CHEN Y., GANG C., AN R., LI J. Vegetation dynamics and its driving forces from climate change and human activities in the ThreeRiver Source Region, China from 1982 to 2012. Science of the Total Environment, 563, 210, 2016.

13. MARINI L., NASCIMBENE J., SCOTTON M., KLIMEK S. Hydrochemistry, water table depth and related distribution patterns of vascular plants in a mixed mire. Plant biosystems, 142 (1), 79, 2008.

14. AMORIM P.K., BATALHA M.A. Soil-vegetation relationships in hyperseasonal cerrado, seasonal cerrado, and wet grassland in Emas National Park (central Brazil). Acta Ecological, 32 (3), 319, 2007.

15. LOZANO-GARCÍA B., PARRAS-ALCÁNTARA L., BREVIK E.C. Impact of topographic aspect and vegetation (native and reforested areas) on soil organic carbon and nitrogen budgets in Mediterranean natural areas. Science of the Total Environment, 544, 963, 2016.

16. JAFARI M., CHAHOUKI M.Z., TAVILI A., AZARNIVAND H., AMIRI G.Z. Effective environmental factors in the distribution of vegetation types in Poshtkouh rangelands of Yazd Province (Iran). Journal of Arid Environments, 56 (4), 627, 2004.

17. FERRARO D.O., GHERSA C.M. Quantifying the crop management influence on arable soil condition in the Inland Pampa (Argentina). Geoderma, 141 (1-2), 43, 2007.

18. BRUELHEIDE H., UDELHOVEN P. Correspondence of the fine-scale spatial variation in soil chemistry and the herb layer vegetation in beech forests. Forest Ecology and Management, 210 (1-3), 205, 2005.

19. FU B,J., LIU S.L., MA K.M., ZHU Y.G. Relationships between soil characteristics, topography and plant diversity in a heterogeneous deciduous broad-leaved forest near Beijing, China. Plant and soil, 261 (1-2), 47, 2004.

20. SHEN W., ZHU N., CUI J., WANG H., DANG Z., WU P., SHI C. Ecotoxicity monitoring and bioindicator screening of oil-contaminated soil during bioremediation. Ecotoxicology and Environmental Safety, 124, 120, 2016.

21. BUTT M.A., ALI A., IJAZ S., MEHMOOD R., MAHMOOD S.A., JAFFER G., MIRZA A.I. Flood Frequency Analysis of Chenab River for Predicting Peak Flows during Late Monsoon Period. Advances in Remote Sensing, 8 (01), 1, 2019.

22. ANONYMOUS. Pakistan. Agriculture Wing. Planning Unit, Pakistan. Food and Agriculture Division, Planning Unit, 2011.

23. HUSSAIN K., NISAR M.F., MAJEED A., NAWAZ K., BHATTI K.H. Ethnomedicinal survey for important plants of Jalalpur Jattan, district Gujrat, Punjab, Pakistan. Ethnobotanical Leaflets, 2010 (7), 11, 2010.

24. KHAN M., HUSSAIN F., MUSHARAF S. Classification and Ordination of Vegetation in Shahbaz Gari, District Mardan. Journal of Biological Sciences, 15, 9, 2015.

25. BASHIR H., AHMAD S.S., NAWAZ M., SHAHZAD S., GISHKORI R., JAWAD Y. Ordinal Quantification of Weed Status at Khanpur Dam, Pakistan. Pakistan Journal of Life \& Social Sciences, 16 (1), 2018.

26. ESTEFAN G., SOMMER R., RYAN J. Methods of soil, plant, and water analysis. A manual for the West Asia and North Africa region, 170, 2013.v

27. WALKLEY A.Y., BLACK I.A. A critical examination of rapid method for determining organic carbon in soils. Soil. Sci, 63, 1974.

28. OLSEN S.R. Estimation of available phosphorus in soils by extraction with sodium bicarbonate (No. 939). US Department of Agriculture, 1954.

29. SIMS J.T. Soil test phosphorus: Olsen P. Methods of phosphorus analysis for soils, sediments, residuals, and waters, 20. 2000.

30. LU G.Y., WONG D.W. An adaptive inverse-distance weighting spatial interpolation technique. Computers \& geosciences, 34 (9), 1044, 2008.

31. BASHIR H., AHMAD S.S., JABEEN A., ERUM S. Multivariate analysis for the assessment of herbaceous roadsides vegetation of wah cantonment. JAPS: Journal of Animal \& Plant Sciences, 26 (2), 2016. 
32. KHAN Y., GULSHAD K., AHMAD S.S., BASHIR H., ERUM, S. Differential responses of Vegetation along Effective Soil Gradients in Mughal Garden Wah, Pakistan. International Journal of Economic and Environmental Geology, 36, 2016.

33. ZIA A., AHMAD S.S., BASHIR H. Assessment of Vegetation-Edaphic Correlation of Wetland Complex of Soon Valley, Pakistan using Multivariate Techniques. Biological Sciences-PJSIR, 61 (1), 21, 2018.

34. ZEREEN A., AHMAD S.S., JAHAN A. Determination of correlation between plant distribution and ecological factors in Narowal district Punjab, Pakistan. Bangladesh Journal of Botany, 47 (3), 451, 2018.
35. UROOJ R., AHMAD S.S., AHMAD M.N., AHMAD H., NAWAZ M. Ordination study of vegetation analysis around wetland area: a case study of Mangla dam, Azad Kashmir, Pakistan. Pakistan Journal of Botany, 48 (1), 115, 2016.

36. KAMO T., ENDO M., SATO M., KASAHARA R., YAMAYA H., HIRADATE S., HIROTA M. Limited distribution of natural cyanamide in higher plants: occurrence in Vicia villosa subsp. varia, V. cracca, and Robinia pseudo-acacia. Phytochemistry, 69 (5), 1166, 2008. 